\title{
A PROPOSED NATIONAL CURRICULUM IN ANAESTHESIA
}

\author{
Commentary by P.J. Tomlin and C.D. Green†
}

IN 1971, at the Conference of Heads of University Departments of Anaesthesia in Canada, a committee was established to formulate a National Curriculum in Anaesthesia. The desirability of having such a Curriculum had become apparent for a number of reasons. Resident trainees were finding it increasingly difficult to prepare for their specialist examinations as the level of knowledge increased. This was particularly so in the fringe areas where anaesthesia overlaps with general medicine or general surgery. Out of this arose the idea that the curriculum should attempt to define the level of knowledge that a competent anaesthetist should have for each topic listed. Hitherto, the level of knowledge has never been defined in advance for any specialist medical examination with which we are acquainted. Candidates could only find the level of knowledge expected of them by trial and failure, or by hearsay reporting by colleagues. This was felt to be wasteful in that some candidates over prepare in one aspect and under prepare in another aspect of their discipline, sometimes to their detriment.

Another advantage of defining, in some detail, what should be taught and to what academic level, was that it would at least provide a useful guide to the teachers in the medical schools to what minimum common knowledge would-be anaesthetists would be expected to have. This, in turn, led to the "common core" concept which is discussed in the proposals. Finally, it was felt that such proposals might provide a useful guide to the examiners for our Fellowship.

Practical training was also considered and this proved rather more intractable. It is of interest that Anaesthetists in other countries have also had difficulties in defining what was desirable and in trying to match this to both the national clinical need and the available teaching resources. However, a set of proposals was arrived at and these seemed to be realistic. These were accepted for initial evaluation at the meeting of the Conference of University Chairmen of Anaesthesia in 1973.

Since the proposals were discussed by the Heads of Departments in May 1973 considerable interest has been aroused not only in Canada, but also in the United States and in the United Kingdom. A number of departments are actively evaluating the proposals, though it should be appreciated that they are, at the moment, only proposals. It has not been formally agreed by anyone that these proposals should be adopted. It is more likely that, as the departments report their evaluations, modifications will be introduced. Indeed, it is to be hoped that if the concept of a National Curriculum should be acceptable and if the details

-Special advisor to the ad hoc committee on National Curriculum, Visiting Professor of Anaesthesia, Memorial University of Newfoundland, Senior Lecturer, Department of Anaesthesia, University of Birmingham.

fChairman of ad hoc committee on National Curriculum, Professor and Chairman of Anaesthesia, Memorial University of Newfoundland. 
are agreed, that there would be frequent revisions of the curriculum as knowledge increases and the relative importance of subjects changes.

It is to be hoped that publication of these proposals will lead individuals and departments to discuss them and to consider both their desirability and practicability. Even if the proposals are not acceptable, a start will have been made in attempting to define a National Curriculum.

\section{A PROPOSED NATIONAL CURRICULUM IN ANAESTHESIA}

Croio D. Green, M.D., Chairman ${ }^{1}$

PAul OTton, M.D., F.R.C.P. $(\mathrm{C})^{2}$

EDWARd C. COCKINGS, M.D., F.R.C.P.(C) ${ }^{3}$
RaYNaLd DeRY, M.D., F.R.C.P. (C) ${ }^{4}$

LeONARD C. JENKINS, M.D., F.R.C.P.(C) ${ }^{5}$

Raymond L. MATTHEWS, M.D., F.R.C.P.(C) ${ }^{6}$

Objective: To produce a curriculum aimed at providing a basis for study by candidates for Fellowship of the R.C.P. Canada so that the R.C.P. can certify that the candidate has a sufficient theoretical knowledge and understanding of anaesthesia as well as the practical experience such that he is -

(a) Capable of practising as a specialist in Anaesthesia

(b) Capable of imparting that knowledge to future entrants to the specialty.

Limitations: It is impossible for any candidate to be fully knowledgeable and fluent in all aspects of anaesthesia (in its broadest sense) as the discipline has become so wide. However, he should reach the forefront of the main stream of knowledge in some aspects of the subject, in other aspects he should have a sufficient working knowledge to be able to cope on an emergency basis (e.g., to provide a back-up staff for an I.C.U. while the regular man is off, or hypotensive anaesthesia or paediatric anaesthesia), while for yet other aspects he should be aware of some of the difficulties and be able to deduce some of their solutions from knowledge of the first principles.

However, the areas where the candidate will reach the forefront of the mainstream of knowledge will vary for different students according to their interest and training as well as the interest and expertise of the teachers available in different medical schools.

This introduces a concept that there must be a central core of common knowledge about which each student must be fully informed (and at an examination show that he is so informed), and then a gradual diminution of knowledge in

\footnotetext{
1Professor \& Chairman of Anaesthesia, Memorial University of Newfoundland, St. John's, Newfoundland.

2 Associate Professor of Anaesthesia, McGill University, Montreal, Quebec.

3Professor of Anaesthesia, University of Saskatchewan, Saskatoon, Sask.

${ }^{4}$ Associate Professor, Laval University, Montreal, Quebec.

5Professor and Chairman, Department of Anaesthesia, University of British Columbia, Vancouver, B.C.

${ }^{6}$ Associate Professor of Anaesthesia, University of Toronto.
} 
some areas, until, at the periphery, there will be a need for options for some aspects of anaesthesia so the candidate can show that he has reached the forefront of the mainstream of knowledge in relation to his selected topics or options.

To identify the central core material, as well as some of the peripheral areas, the published courses of lectures given by a number of different institutions, both Canadian and from the United Kingdom, were analyzed. Subjects taught by the majority of institutions were considered central core subjects while others that were taught by only a few institutions were considered progressively more and more peripheral according to the extent of the teaching effort.

The institutions from which specimen teaching programmes were obtained were:

$\begin{array}{ll}\text { CANADIAN } & \text { UNITED KINGDOM } \\ \text { Dalhousie } & \text { Manchester } \\ \text { Toronto } & \text { Oxford } \\ \text { Laval } & \text { Birmingham } \\ \text { Memorial } & \text { Liverpool }\end{array}$

The United Kingdom teaching programmes are orientated around a two part examination - the Primary and Final examinations - and are more compartmentalized and detailed as a result of the published curriculum of The Faculty of Anaesthetists (England) than are the Canadian programmes. The detailed listings of the various topics and their weightings are given in Tables Al-5.

The level of instruction in subjects was to be such that a candidate would reach one of three levels of knowledge identified as follows:

(1) Full grasp of mainstream of knowledge in this topic.

(2) Working knowledge of the general principles of the topic.

(3) Some knowledge is essential.

Alternate definitions which have been suggested are:

(1) the information contained in speciality journals relating to anaesthesia.

(2) the information relating to anaesthesia contained in general medical journals.

(3) the information contained in textbooks. 
TABLE A-1

Pharmacology

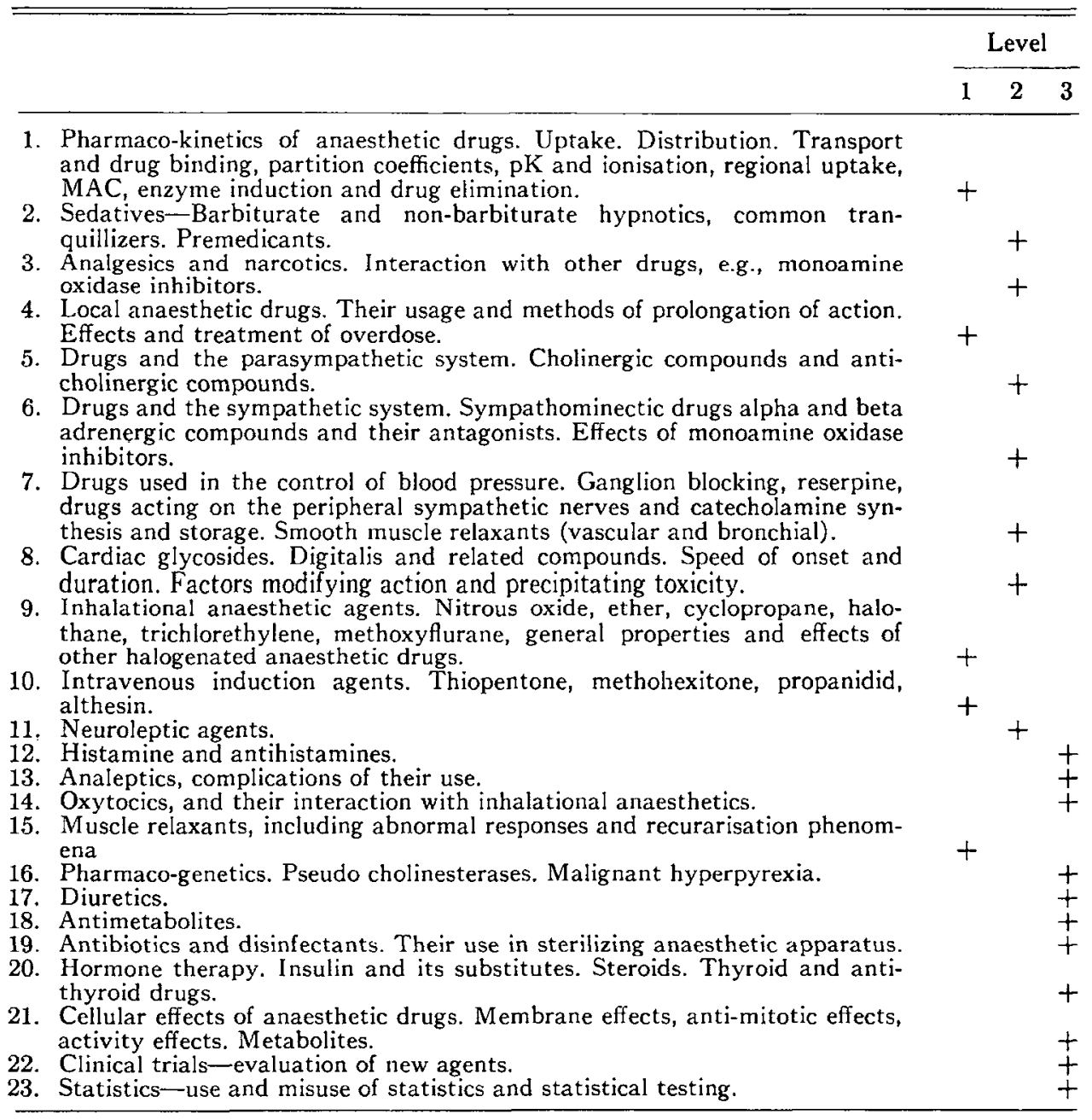

TABLE A-2

PHYSIOLOGY

Level

$12 \quad 3$

Respiration

1. Lung, anatomy, volumes, and capacities. Dead space. Alveolar volume, gas concentrations, methods of measurement. Clinical applications and significance.

2. Lung mechanics. Chest wall and diaphragm mechanics, compliance, (dynamic and static). Resistance, regional compliance, methods of measurements, factors affecting and clinical significance. Surfactant.

3. Ventilation/Perfusion. Stratified and non-stratified, inhomogeneity, the effect of time constants on gas distribution, gas flow and mixing in preterminal and terminal bronchioles. Distribution of $V / Q$ ratios, sources and effects of turbulence. 
TABLE A-2 (continued)

4. Central control of respiration, chemical influences, reflex infuences, somatic
influences. Intrinsic organization. The effects of drugs on the central control.
5. Blood gas transport. Haemoglobin oxygen dissociation curve and factors
modifying. The effect of different haemoglobins and of blood storage. $\mathrm{CO}_{2}$
transport and $\mathrm{CO}_{2}$ dissociation curve.
6. Acid base. Henderson-Hasselbach Equation. Methods of assessment: Nomo-
grams and their use, the Astrup interpolation technique. The effects of com-
pensatory mechanisms on acid base parameters. The in vivo-in vitro differ-
ence. The effects of hypothermia. Methods of treating disturbances.
7. Pulmonary circulation. Distribution of blood flow through the lungs. Pul-
monary vascular resistance. Factors modifying mechanisms of pulmonary
oedema. Shunts (anatomical and "physiological"). Pulmonary circulation
time and its effects on gas uptake and elimination. The effects of venous
desaturation and pulmonary circulation time on gas uptake.

\section{Cardiovascular}

1. The cardiac cycle, synchronisation of pressure, flow, heart sound, ECG, valve activity. Impulse propagation and factors affecting.

2. Ventricular function curves and factors modifying. $\mathrm{dP} / \mathrm{dt}$ isometric and isotonic contraction. Effects of preload and afterload. Effects of ionic disturbances.

3. Blood pressure and flow. Cardiac output and factors affecting. Distribution of cardiac output, total peripheral resistance and factors affecting, regional flow wave velocity, pressure wave velocity. Blood pressure, mean pressure, and factors affecting.

4. The micro circulation. Arteriole-capillary-venule flow. Peripheral a-v shunts. Pre- and post-capillary sphincter control. Factors affecting this control. Viscosity of blood, sluding. The control of blood volume. Extra cellular fuid formation.

5. Central control of the circulation, vasomotor centre, vasomotor tone, and factors affecting this. Pressor receptors and pressor reflexes. Effect of parasympathetic and sympathetic overactivity and underactivity.

\section{Central Nervous System}

1. Resting membrane potentials, action potentials, end plate potentials, impulse propagation and velocity and factors modifying. Energy supply and utilization.

2. Neuro-muscular and synaptic transmission. Receptors, transmittors, precursors, and factors affecting.

3. Muscle tone. Muscle spindle reflexes and factors affecting. Anterior Horn Cell activity and factors affecting.

4. Sensory Perception. Sensory endings and sensory pathways. Cortical representation.

5. Cerebro-spinal-fluid. Its formation, flow, volume, and factors modifying.

6 . Temperature control.

7. E.E.G. and the effects of anaesthesia on the E.E.G.

8. Cerebral blood flow, factors affecting. Brain volume control, intracranial pressure and factors affecting.

Renal Physiology

1. Glomerular function, tubular function. Renal function tests. Renal blood flow.

2. Water balance, electrolyte balance, effects of disturbances. Renal influences on acid base balance. (See \#6 Respiration).

3. Renal hormones, the control of blood volume.

Liver

Liver function tests. Liver perfusion and excretion functions. Glycogen mobilization.

Level

$\begin{array}{lll}1 & 2 & 3\end{array}$ $+$

$+$

3 
TABLE A-2 (continut)

\begin{tabular}{l}
\hline \hline \\
$\begin{array}{l}\text { Endocrine } \\
\text { The control of the blood sugar, steroid secretion, pituitary function. The effect } \\
\text { of disturbances of endocrines. }\end{array}$ \\
$\begin{array}{l}\text { Newborn } \\
\text { Foetal circulation and changes at birth. Neonatal ventilation. The effects of } \\
\text { asphyxia. Its complications and the complications of its treatment. } \\
\text { Hatmatology } \\
\text { Normal and abnormal haemoglobins, clotting and clot lysis. Cell fragility and } \\
\text { haemolysis. Blood groups, blood transfusion and blood substitutes. }\end{array}$ \\
\hline
\end{tabular}

TABLE A-3

Physics

Measurement and Chemistry

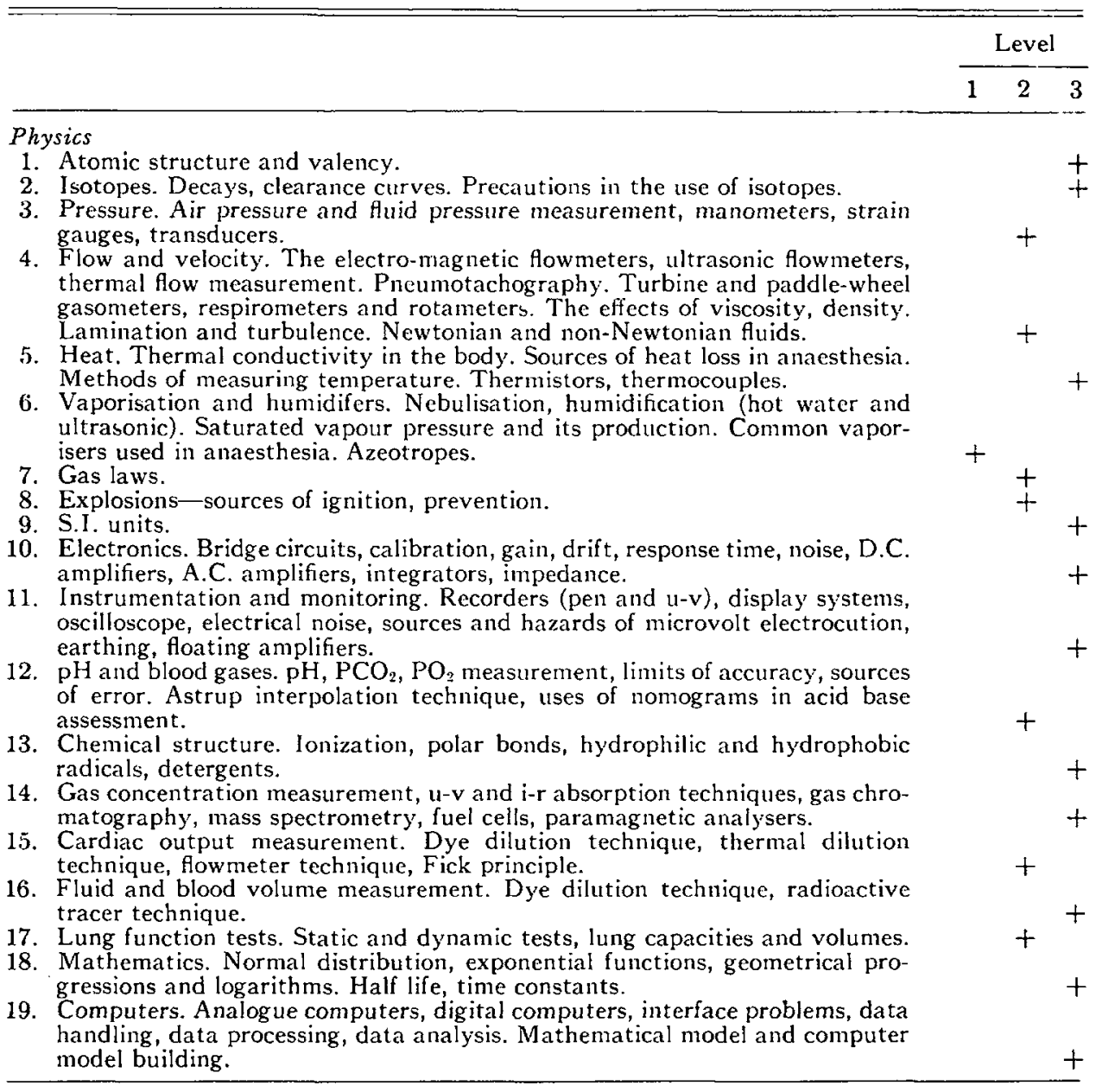


TABLE A-5

MEDicine

The general medical topics with special emphasis on their relation to Anaesthesia. The level of training to be such that the candidate can reach the following standards in each topic.

1. Specialist (general internist)

2. Family practitioner after 2 years of training

3. Current Medical Student at time of graduation from medical school.

Cardio-Vascular System

1. Valvular disease (M.S., M.I., A.S., A.I., P.S., P.I.)

Clinical diagnosis and management of patients with chronic valvular disease. Preoperative and postoperative care of patients with valvular disease undergoing elective surgery.

2. Ischaemic heart disease

Clinical presentation, the commoner E.C.G. changes of ischaemic heart disease. Factors precipitating acute ischaemic episodes and methods of relieving acute attacks.

3. Rhythm disorders

Diagnosis and management. Atrial fibrillation, atrial futter bundle branch block, heart block, atrial defibrillation. Pacemaking. Ventricular extrasystoles, ventricular tachycardia. Supra ventricular tachycardia.

4. Acule and Chronic Heart Failure

Acute pulmonary oedema and methods of treatment. The use of I.P.P.B. in acute pulmonary oedema. Acute right ventricular failure and its management. Chronic left ventricular failure and pulmonary hypertension. Other causes of pulmonary hypertension. Chronic right ventricular failure. Methods of treatment, conplications of treatment. Effects of sodium, potassium depletion.

5. Myocardial Infarction

Presentation, prognosis, treatment and recovery patterns. Factors precipitating a second infarct. Management of patients with an acute infarct.

C.C.U. and the role of an anaesthetist. Immediate after care of patient with cardiac arrent (both respiratory and circulatory).

Anaesthesia in patients with myocardial infarction.

6. Hypertension

Presentation, methods of diagnosis, classification and clinical management.

The interaction of drugs used in the treatment of hypertension with anaesthetic drugs.

Respiratory System

1. Chronic Bronchitis

Obstructive airway disease, its effects on gas distribution in the lungs and on blood gases. Clinical management of chronic bronchitis with or without emphysema. Effects of chronic bronchitis and emphysema on pulmonary circulation.

2. Asthma

Aetiology. Management of patients with asthma, after care. Blood gas changes. Methods of treatment of an acute attack and of status asthmaticus.

The use of ventilators and anaesthetic drugs in status asthmaticus. Effects of variable wave form flow on gas distribution and factors affecting choice of ventilator.

3. Chronic Respiratory Failure

Blood gas changes, diagnosis and management. The use of controlled oxygen therapy. Management of acute or chronic respiratory failure.

Use of I.P.P.B., problems of weaning, after care. Home use of ventilators.

4. Respiratory Cripple and Anaesthesia

Methods of achieving optimum pre-operative status. Factors affecting choice of drugs and anaesthesia.

Use of artificial ventilation during anaesthesia in the respiratory cripple. Relaxant reversal and problems associated. Post operative care, oxygen therapy, inhalation therapy. Problems associated with the use of analgesics in the post operative period.

Central Nervous System

1. Tetanus. Clinical presentation, management of the mild attack. Indications for the use of relaxants and J.P.P.B. Autonomic convulsions and their management 
TABLE A-5 (continued)

Grading

2. Poliomyelitis

Presentation and disease progress. The use of chronic I.P.P.B. in chronic poliomyelitis.

Use of Cuirass ventilators, body box negative pressure ventilators.

3. Myasthenia Gravis

Medical management, indications for thymectomy.

Treatment of a myasthenic crisis. Treatment of respiratory infection in a myas-

thenic or in a patient with other severe muscular dystrophies.

Anaesthesia in a myasthenic undergoing elective surgery, thymectomy. Post operative care.

4. Coma

Differential diagnosis. Clinical management. Airway problems and their management. The use of artificial ventilation in patients with coma. Indications for hypothermia and methods of establishing this. Use of osmotic diurectics.

Other Diseases

1. Liver disease

Acute liver disease, drugs precipitating acute liver disease, chronic liver failure methods of diagnosis.

Choice of anaesthesia in patients with chronic liver disease.

2. Steroid Therapy

Indications for steroid replacement therapy and immunosuppressive therapy.

Anaesthetic management of patients on steroids, and aftercare.

3. Diabetes

Drugs used in the control of blood sugar.

Anaesthetic management of a diabetic for elective or emergency surgery. Post operative care, treatment of diabetic coma.

4. Phaeochromocyloma

Clinical diagnosis and medical management.

Preoperative preparation and anaesthetic management of surgical treatment of this.

5. Thyroid Disease

Medical management, indications for surgery. Preoperative preparation.

Anaesthetic management for thyroid surgery. Thyrotoxic crisis and management, use of hypothermia, complications of thyroid disease and their effects in anaesthesia.

6. Electrolyle Imbalance

Sodium, potassium, calcium, magnesium. Aetiology. Effects of electrolyte imbalance on normal physiology and on the pharmacology of other drugs.

7. Carcinoid Syndrome

Clinical presentation.

Respiratory complications and their management.

Radiology

1. Radiological assessment of lung disorders

The normal chest film. Atelactasis, segmental collapse, pneumonitis, pulmonary oedema, interstitial oedema, pneumothorax, pleural effusion.

2. Radiological assessment of heart disorders

Right ventricular hypertrophy, left ventricular hypertrophy, acute pulmonary hypertension. Radiological assessment (Plain films only) of patients with the commoner congenital heart diseases. 


\section{Practical Training}

So far only the theoretical content of the national curriculum has been discussed. Practical training includes Operating Room training and Bedside Training up to the level where the candidate should be able to perform on his own. There are limitations in resources for practical training, e.g., few centres are likely to be practicing all aspects of anaesthesia in enough quantity for all their trainees to acquire fluency in the practical management of all and every different type of case. Equally, the national need for all trainees to be fluent in every practical aspect of anaesthesia is not readily apparent (e.g., there is not an obvious national need that every specialist should be, let us say, an expert neuro-anaesthetist, or expert in managing cardiopulmonary by-pass patients, though there may well be a national need for every specialist anaesthetist to be expert in managing patients with multiple injuries, or obstetrical patients). In addition, there are fields where the anaesthetist need not necessarily be expert to undertake all routine work, but should be able to cope with emergency situations in that field, e.g., while there may not be a need for every anaesthetist to be an expert neuro-anaesthetist, yet everyone should be able to care for patients undergoing burr hole operations for subdural haematoma.

It would seem desirable, therefore, that the trainees obtain a series of credits for different aspects of practical training, that a substantial number of these credits should be compulsory, while others are optional, though each trainee must obtain credit in some of the options. To this end a list of topics has been produced and two levels of proficiency for each topic have been indicated (See Table "B"). These levels relate to proficiency to undertake routine work in that field, and proficiency to undertake emergency work in that field. Routine work is defined as the clinical work undertaken by the majority of clinicians in that field.

It is tentatively suggested that the curriculum for practical training should be all the topics listed in the E (Essential) topics listed in Table "B," that there should be, in addition, a substantial practical training obtained in at least six of the topics in the "D" (Desirable) and " $U$ " (Useful) categories from the routine clinical work list, and a further additional two credits obtained from the " $D$ " or " $U$ " list in the Emergency work topic list. From Table " $B$ " it will be seen that all the topics listed under " $E$ " in either column are considered central core topics for practical training and the list offers also some options among the " $D$ " and " $U$ " categories. In the selection of options preference should be for the trainee to acquire practical experience in some of the " $D$ " rather than " $U$ " listed topics, and for anaesthesia departments to ensure that the practical experience in these topics is available.

Guidance will be needed to indicate what quantity of practical training and proficiency is to be expected before either of the two grades to that credit for that topic can be awarded. The grading and allocation of the credits will have to be by the local teachers and a copy could, perhaps, be lodged with the Royal College 
TABLE B

A National Curriculum in Anaesthesia

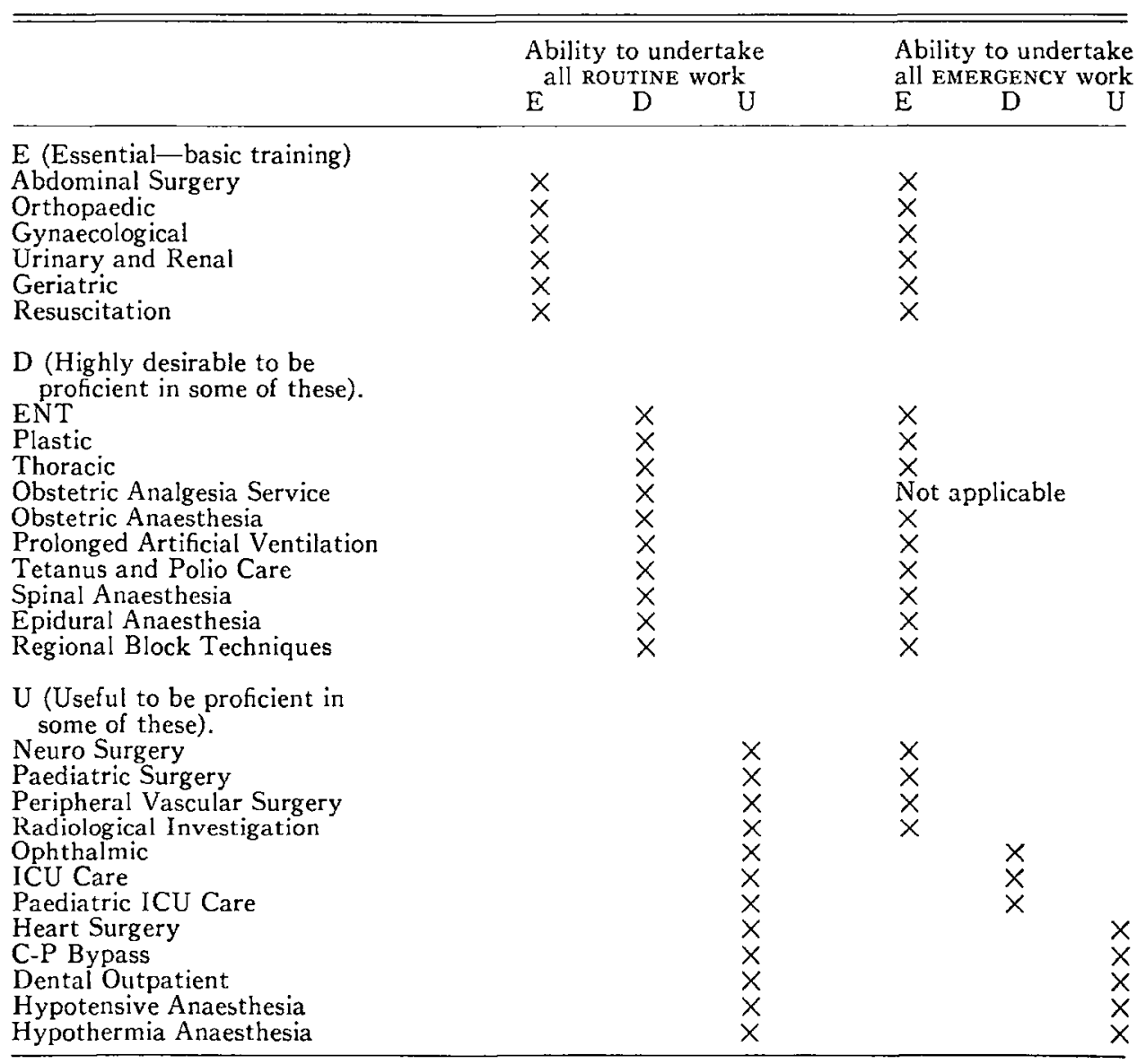

of Physicians so that, in the examination, the trainee's claimed level of proficiency in his option topics could be evaluated. It should thus be realized that these credits simply indicate that the student has passed through this or that aspect of practical training, and has been considered by his local teachers to be rcasonably proficient in that particular aspect of anaesthesia.

\section{Appendix $C$}

\section{SOURCE of Material}

There was considerable variation in both the intensity of teaching effort and subject material for lectures between the various centres and surprisingly little absolute common ground. Thus, of 100 identifiable topics, none was taught by all eight institutions. Though not all eight institutions attempted to be comprehensive, even among the 30 clinical topics, only eight of these were taught by six of the eight teaching centres. The variation in teaching effort between different centres that did teach on the same topic was also very striking; thus of the 24 lectures on artificial ventilation given by six of the eight institutions, one centre 
thought the subject so important as to devote no less than 16 lectures and demonstrations to it. Similarly five centres considered that some teaching in general medicine was desirable and of the 47 lectures given in general medicine no less than 32 were given by one institution. At the other extreme, radiological interpretation was taught in only one institution where no less than six lectures were devoted to it.

There are also several differences between the British lecture courses and the Canadian; there was considerably more effort in teaching the basic sciences in the British courses, notably in the teaching of Physiology of the central nervous system, on Physics and Measurement tuition and on electronics and monitoring instrumentation. Anatomy was much more heavily taught by the Canadian centres than in their British counterparts. These differences are presumably related to the two-part FFA examination held in England. Of the Clinical topics - Operating Room Anaesthesia for all the specialized types of surgery was taught equally as intensively by both countries, with the possible exception of Obstetric Anaesthesia which was taught more in the British centres. Outside the Operating Room, I.C.U. topics such as oxygen therapy, artificial ventilation, tetanus and poliomyelitis were considerably more intensively taught by the British centres; whereas the teaching on "Shock" received relatively little effort in the British Schools. Notwithstanding all this, the basic core material, the theoretical and clinical anaesthesia taught between the British Centres and the Canadian Centres, was not very dissimilar. The total number of lectures given and the number of Centres giving these lectures on each topic is listed in Tables $\mathrm{Cl}$ and 2. The top ten topics to which the most effort was devoted is given in Table $\mathrm{D}$. The degree of agreement between the various centres is given in Table $\mathrm{E}$.

TABLE $\mathrm{C}-1$

Total No. of Lectures and Nos. of Centres Teaching

\begin{tabular}{|c|c|c|c|c|c|c|c|c|}
\hline \multirow[b]{2}{*}{ Subject } & \multicolumn{8}{|c|}{ Centres } \\
\hline & 8 & 7 & 6 & 5 & 4 & 3 & 2 & 1 \\
\hline $\begin{array}{l}\text { Pharmacology-General } \\
\text { Pharmacokinetics } \\
\text { Sedatives } \\
\text { Analgesia } \\
\text { I.V. Agents }\end{array}$ & & & 19 & 7 & 5 & 3 & & 8 \\
\hline $\begin{array}{l}\text { G.A. Inhalational Agents } \\
\text { Local Agents } \\
\text { Relaxants } \\
\text { Autonomic S.V. System } \\
\text { Neurolepts } \\
\text { C. Glycosides }\end{array}$ & & 13 & 11 & $\begin{array}{r}19 \\
6\end{array}$ & $\begin{array}{l}7 \\
5\end{array}$ & & & \\
\hline $\begin{array}{l}\text { Endocrine Drugs } \\
\text { Antihistamines, Analeptics, Etc. } \\
\text { Drug Interaction } \\
\text { Cellular Effects } \\
\text { Drug Trials \& Statistics } \\
\text { Pharmacogenetics } \\
\text { Overdose }\end{array}$ & & & & & & 12 & 3 & 1 \\
\hline
\end{tabular}

The numbers in the columns indicate the total numbers of lectures given by the number of centres teaching a given subject. 
TABLE C-2

Total No. of Lectures and Nos. of Centres Teaching

\begin{tabular}{|c|c|c|c|c|c|c|c|c|}
\hline \multirow[b]{2}{*}{ Subject } & \multicolumn{8}{|c|}{ Centres } \\
\hline & 8 & 7 & 6 & 5 & 4 & 3 & 2 & 1 \\
\hline $\begin{array}{l}\text { Physics, Measurement, Bioc } \\
\text { Atomic } \\
\text { Pressure } \\
\text { Flow }\end{array}$ & & & 11 & 12 & & & & 1 \\
\hline $\begin{array}{l}\text { Vapours \& Humidification } \\
\text { Explosions } \\
\text { Gas Laws } \\
\text { Liquids } \\
\text { Units }\end{array}$ & & & 10 & 5 & 4 & 4 & & 1 \\
\hline $\begin{array}{l}\text { Isotopes } \\
\text { Electronics } \\
\text { Instrumentation } \\
\text { pH + Blood Gases } \\
\text { Gasometry } \\
\text { Cardiac Output } \\
\text { Lung function Tests } \\
\text { Blood Volume }\end{array}$ & & & & & $\begin{array}{l}7 \\
7 \\
6\end{array}$ & $\begin{array}{l}2 \\
3\end{array}$ & & 2 \\
\hline
\end{tabular}

The numbers in the columns indicate the total numbers of lectures given by the number of centres teaching a given subject.

TABLE $\mathrm{C}-3$

Total No, of Lectures and Nos. of Centres Teaching

\begin{tabular}{|c|c|c|c|c|c|c|c|c|}
\hline \multirow[b]{2}{*}{ Subject } & \multicolumn{8}{|c|}{ Centres } \\
\hline & 8 & 7 & 6 & 5 & 4 & 3 & 2 & 1 \\
\hline $\begin{array}{l}\text { Biochemistry } \\
\text { Chemical Structure } \\
\text { Mathematics } \\
\text { Computers } \\
\text { General Medicine } \\
\text { Radiology }\end{array}$ & & & & 47 & 6 & $\begin{array}{l}2 \\
5\end{array}$ & 6 & 6 \\
\hline $\begin{array}{l}\text { Physiology } \\
\text { C.V.S. General } \\
\text { Heart } \\
\text { Regional Circ } \\
\text { Micro Circ } \\
\text { Control of Circ } \\
\text { ECG }\end{array}$ & & & & 13 & $\begin{array}{r}11 \\
4\end{array}$ & & $\begin{array}{l}2 \\
5\end{array}$ & \\
\hline $\begin{array}{l}\text { Resp. System General } \\
\text { Lung Mechanics } \\
V / Q \\
\text { Central Control } \\
\text { Gas Transport }\end{array}$ & & & 25 & 6 & 9 & 7 & 3 & \\
\hline
\end{tabular}

The number in the columns indicate the total numbers of lectures given by the number of centres teaching a given subject. 
GREEN, et al.: PROPOSED NATIONAL CURRICULUM IN ANAESTHESIA

TABLE C-4

Total No. of Lectures and Nos. of Centres Teaching

\begin{tabular}{|c|c|c|c|c|c|c|c|c|}
\hline \multirow[b]{2}{*}{ Subject } & \multicolumn{8}{|c|}{ Centres } \\
\hline & 8 & 7 & 6 & 5 & 4 & 3 & 2 & 1 \\
\hline $\begin{array}{l}\text { Acid Base } \\
\text { Pulmonary Circ } \\
\text { CNS. General } \\
\text { Autonomic } \\
\text { Neuromusc. + Tone }\end{array}$ & & & & 9 & 9 & 10 & 2 & 2 \\
\hline $\begin{array}{l}\text { Reflexes } \\
\text { Sensation } \\
\text { Csf } \\
\text { Temperature } \\
\text { EEG }\end{array}$ & & & & & & $\begin{array}{l}4 \\
5\end{array}$ & 2 & 1 \\
\hline $\begin{array}{l}\text { Renal } \\
\mathrm{H}_{2} \mathrm{O}+\text { Electrolyte } \\
\text { Endocrine } \\
\text { Liver } \\
\text { Metabolism }\end{array}$ & & & & $\begin{array}{l}13 \\
14\end{array}$ & $\begin{array}{l}9 \\
7\end{array}$ & & & \\
\hline $\begin{array}{l}\text { Newborn } \\
\text { Haematology }\end{array}$ & & & & & 8 & & & 3 \\
\hline
\end{tabular}

The numbers in the columns indicate the total numbers of lectures given by the number of centres teaching a given subject.

TABLE C-5

Total No. of Lectures and Nos. of Centres Teaching

\begin{tabular}{|c|c|c|c|c|c|c|c|c|}
\hline \multirow[b]{2}{*}{ Subject } & \multicolumn{8}{|c|}{ Centres } \\
\hline & 8 & 7 & 6 & 5 & 4 & 3 & 2 & 1 \\
\hline $\begin{array}{l}\text { Anatomy } \\
\text { History } \\
\text { Circuits \& Machines } \\
\text { Assessment of Patient } \\
\text { Premedication } \\
\text { Endocrine Aspects }\end{array}$ & & & & 7 & $\begin{array}{l}22 \\
11\end{array}$ & 6 & 3 & 1 \\
\hline $\begin{array}{l}\text { Blood \& Infusion } \\
\text { Psychological Aspects } \\
\mathrm{O}_{2} \text { Therapy } \\
\text { Pain Control } \\
\text { Blocks }\end{array}$ & & 17 & $\begin{array}{r}9 \\
24\end{array}$ & & & & 2 & 1 \\
\hline $\begin{array}{l}\text { Complications } \\
\text { I.T.U. } \\
\text { Tetanus \& Polio } \\
\text { Artificial Ventilation } \\
\text { Resuscitation }\end{array}$ & & & $\begin{array}{l}24 \\
12\end{array}$ & & 10 & & 2 & \\
\hline Shock & & & & & 8 & & & \\
\hline
\end{tabular}

The numbers in the columns indicate the total number of lectures given by the number of centres teaching a given subject. 
TABLE C-6

Total No. of Lectures and Nos. of Centres Teaching

\begin{tabular}{|c|c|c|c|c|c|c|c|c|}
\hline \multirow[b]{2}{*}{ Subject } & \multicolumn{8}{|c|}{ Centres } \\
\hline & 8 & 7 & 6 & 5 & 4 & 3 & 2 & 1 \\
\hline $\begin{array}{l}\text { Overdose } \\
\text { Specials. C-p Bypass } \\
\text { Hypotensive } \\
\text { Hypothermia }\end{array}$ & & & & & 7 & $\begin{array}{l}3 \\
3\end{array}$ & & 1 \\
\hline $\begin{array}{l}\text { Neuroleptic } \\
\text { Emergency } \\
\text { Obstetrical } \\
\text { Dental } \\
\text { Paediatric }\end{array}$ & & & 17 & 11 & & $\begin{array}{l}3 \\
6\end{array}$ & & 1 \\
\hline $\begin{array}{l}\text { Geriatric } \\
\text { Peripheral Vascular } \\
\text { Thoracic } \\
\text { Neurosurgery } \\
\text { Radiological }\end{array}$ & & & 7 & 8 & & $\begin{array}{l}3 \\
3\end{array}$ & 3 & \\
\hline Plastic \& ENT & & & & & & & 2 & \\
\hline
\end{tabular}

The numbers in the columns indicate the total number of lectures given by the number of centres teaching a given subject.

TABLE D

Total No. of Lectures and Nos. of Centres Teaching

\begin{tabular}{|c|c|c|c|c|c|c|c|c|}
\hline \multirow[b]{2}{*}{ Subject } & \multicolumn{8}{|c|}{ Centres } \\
\hline & 8 & 7 & 6 & 5 & 4 & 3 & 2 & 1 \\
\hline $\begin{array}{l}\text { Top Ten-Intensity of Teaching } \\
\text { General Medicine } \\
\text { Physiology Resp. System } \\
\text { Artificial Ventilation } \\
\text { Anatomy } \\
\text { Inhalational Agents }\end{array}$ & & & & $\begin{array}{l}47 \\
25 \\
24 \\
\\
19\end{array}$ & 22 & & & \\
\hline $\begin{array}{l}\text { Pharmacokinetics } \\
\text { Regional Blocks } \\
\text { Transfusion \& Infusion } \\
\text { Water \& Electrolytes } \\
\text { Complications of Anaesthesia }\end{array}$ & & 17 & 14 & 19 & & & & \\
\hline
\end{tabular}

TABLE E

Degree of Agreement, Between 8 Institutions, OF TOPICS THAT ARE TAUGHT

\begin{tabular}{cc}
\hline $\begin{array}{c}\text { No. of } \\
\text { Institutions }\end{array}$ & $\begin{array}{c}\text { No. of Topics } \\
\text { in Common }\end{array}$ \\
\hline 8 & 0 \\
7 & 2 \\
6 & 12 \\
5 & 15 \\
4 & 21 \\
3 & 20 \\
2 & 14 \\
1 & 16 \\
\hline
\end{tabular}

i.e., 16 topics taught by one or other institution. i.e., 0 topics taught by all 8 institutions. 
SUMMARY

The published curricula of eight institutions offering Postgraduate Training in Anaesthesia were analysed for agreement in content. From this analysis a proposed curriculum was produced. The curriculum is thought to be unique in that the level of proficiency in each topic is indicated.

\section{RÉSUMÉ}

Les programmes d'études publiés par huit institutions offrant un entraînement post-doctoral en Anesthésie ont été analysés quant à la concordance de leur contenu. Cette analyse a donné suite à la mise au point d'un programme d'études qui semble unique en ceci que le niveau de compétence en chaque matière y est indiqué. 